CDD 576.58

CDU 575.224.2(812.1+811.5)

UNIVERSIDADE DE SÃO PAULO

INSTITUTO DE BIOCIÊNCIAS

DEPARTAMENTO DE BIOLOGIA

O GENE DA FIBROSE CÍSTICA EM DIFERENTES GRUPOS POPULACIONAIS

Emygdia Rosa do Rêgo Barros

Pires Leal Mesquita

Tese apresentada para obtenção do título de Doutor em Ciências Biológicas (área Biologia/Genética). 


\section{O GENE DA FIBROSE CÍSTICA EM DIFERENTES GRUPOS POPULACIONAIS}

Emygdia Rosa do Rêgo Barros Pires Leal Mesquita

Aprovada em / /

BANCA EXAMINADORA

Dra. Mayana Zatz (Orientadora) 
Ao meu marido Chico, às minhas filhas Malu e Guta, ao meu pai Mário, ao meu irmão Marcos, aos meus tios, cunhados e sobrinhos, pelo carinho, apoio e incentivo e pelo amor, elementos essenciais em todas as minhas realizações e no significado de nossas vidas 
A Margarida, minha mãe, cujo exemplo de paixão, de fibra, de competência, de equilíbrio, de amizade e de coerência, me apontou os caminhos éticos, pessoais e profissionais 
À lembrança querida e saudosa dos meus avós, de tia Nena, tio Leal, tia Mary, tio Dalvancy, Vôquim, Dona Rosa, e dos primos José Ricardo, Juliana e Domingos José 


\section{AGRADECIMENTOS}

A Dra. Mayana Zatz, que me conduziu, com sua vasta experiência e capacidade profissional, na conquista deste objetivo de importância ímpar em minha vida

A Dra. Yatiyo Yonenaga-Yassuda, que me iniciou na pesquisa científica de pós-graduação, minha Orientadora de Mestrado e incentivadora deste doutoramento

A Dr. Warwick Estevam Kerr, que me introduziu na vida científica, ainda no Curso de Graduação em Ciências Biológicas da UFMA

Às Dras. Maria Rita Passos-Bueno, Cristina Miyaki, Sabine Eggers e Angela M. Vianna-Morgante, pela atenção e apoio, expressos nas sugestões e dicas importantes ao enriquecimento desta pesquisa

A Dra. Lygia da Veiga Pereira, pelo incentivo recebido

A Dr. Paulo A. Otto, pelo estímulo através de sua descontração e extrema competência nos cálculos estatísticos

A Dra. Regina C. Mingroni-Netto, pelo companheirismo e pela parceira em parte das amostras

A Dra. Mariz Vainzof, pelo apoio na parte fotográfica

A Dra Rita Pavanello, sempre tão gentil

A Constância, pela grande força, em todos os sentidos, no laboratório da Dra. Mayana Zatz

A Andréa Bernardino, pelo incansável apoio

Aos colegas do laboratório, ao grupo das chamadas Luluzinhas: Toninha, Kikue, Lúcia, Manuela, Flavinha, Dulci, Elisângela, Cyntia, Kelly, Agnes, Alex Splendore, Flávia Errera, Paula, Luciana, Camila, Rita Viegas, Fernanda, Dinamar, Alex Starling, Viviane, Telma e Marta; ao grupo dos chamados Bolinhas: Todd, Carlos, Cleber, Oscar, Daniel e Neto, pelo apoio, amizade e companheirismo

A Valéria, Jô e Kátia, pela amizade de sempre 
Ao Departamento de Biologia e ao Instituto de Biociências da Universidade de São Paulo, nas pessoas da Dra. Célia Koiffmann, Coordenadora da Pós-Graduação - área Biologia/Genética. À querida Deisy, secretária da Pós-Graduação da Biologia/Genética, a Helenice, da secretaria do Departamento e a Vera Barbosa Lima, secretária da Pós-Graduação do IB-USP

Aos Drs. Ândrea K. C. Ribeiro-dos-Santos, Sidney E. Santos e João Guerreiro, do Laboratório de Genética Humana e Médica do Departamento de Patologia da UFPA, pelo apoio na coleta de amostras no Município de Bequimão, e pelos pacientes paraenses

A Dra. Silma Regina Pereira Martins, amiga e grande parceira no Laboratório de Genética da UFMA. Aos Drs. Sílvio e Murilo, companheiros de laboratório e meus substitutos nas disciplinas do Departamento de Biologia da UFMA durante minhas ausências

UFMA

A todos os meus colegas do Departamento de Biologia da

Aos funcionários do curso de Ciências Biológicas e do Departamento de Biologia do UFMA

A Maria Santana Pereira Viegas, pelo auxílio técnico no Laboratório de Genética do Departamento de Biologia da UFMA

Aos meus alunos, de ontem e de hoje, na orientação e coautoria de inúmeras pesquisas, Maria Raimunda, Rosilene, Íris, Francisca Suely, Marcelo, Aglai Fernanda, Perla, Francileide, Rômulo, Andréa Márcia, Jack-Any, Fábio, Gabriel e Vítor

Às Dras. Karina Abreu (INLAB-MA) e Cláudia Nunes, pelo encaminhamento dos pacientes maranhenses

Às comunidades de Santa Flor, Pontal e Cajual, pela colaboração na realização deste trabalho

Aos amigos Joacílio, Márcio, Carlos Henrique, Aurora da Graça, Cecília, Lusimar, Raimunda Marinho, Marisa Moreira, Cláudia Porto e Marcos, pela normalização e pelo auxílio editorial

A Rubinho, Cristina, Andréa, Bia, Belmino, Tânia, Cândida, Heitor, Dulce, Ameriquinho e Ively que, através da amizade e do calor humano, fizeram menor a imensa saudade de meus familiares

$\mathrm{E}$, finalmente, à CAPES, à FAPESP e ao CNPq/PRONEX, pelo apoio institucional. 